\title{
Sorption Kinetics of Escherichia coli and Salmonella sp on Two Soil Layers Associated with a Groundwater Table in Yaounde, Cameroon (Central Africa)
}

\author{
Moïse Nola ${ }^{1 *}$, Thomas Njiné ${ }^{1}$, Claude Boutin ${ }^{2}$, Pierre Servais ${ }^{3}$, Mohamed Messouli ${ }^{4}$, Louise Marie Ngo Bidjeck ${ }^{5}$, \\ Adolphe Monkiedje ${ }^{1}$, Serge H. Zébazé Togouet ${ }^{1,6}$ and Norbert Kemka ${ }^{1,6}$ \\ ${ }^{1}$ University of Yaounde 1, Faculty of Sciences, Laboratory of General Biology, P.O. Box 812 Yaounde, Cameroon \\ ${ }^{2}$ Université Paul Sabatier CNRS, Laboratoire d'Ecologie Terrestre, UMR 5552, 118 Route de Narbonne, Bât. 4 R3, 31062 \\ Toulouse Cedex 4, France \\ ${ }^{3}$ Université Libre de Bruxelles, Ecologie des Systèmes Aquatiques, Campus de la Plaine CP 221, Boulevard du Triomphe, \\ 1050 Bruxelles, Belgique \\ ${ }^{4}$ Université Cadi Ayyad, Faculté des Sciences Semlalia, Laboratoire d'Hydrobiologie et Ecologie Souterraine, B.P. 2390 \\ Bd Moulay Abdellah, Marrakech, Maroc \\ ${ }^{5}$ University of Yaounde 1, Faculty of Sciences, Laboratory of Applied Geology, P.O. Box 812 Yaounde, Cameroon \\ ${ }^{6}$ Geology Research Institute, Hydrologic Research Centre, P.O. Box 4110 Yaounde, Cameroon \\ *Correspondence to Dr. Moïse Nola. Email: mnola@uycdc.uninet.cm
}

Received: 04 October 2004 / Accepted: 11 April 2005 / Published: 30 December 2005

\begin{abstract}
A laboratory study has been carried out on two soil layers $\left(\mathrm{H}_{\mathrm{X}}\right.$ and $\left.\mathrm{H}_{\mathrm{Y}}\right)$ located above a groundwater table in Yaounde, Cameroon (Central Africa). The main purpose of this study was to assess the retention potential or sorption kinetics of Escherichia coli and Salmonella sp. on these soil layers. For both soil layers, bacterial sorption on soil particles occurred rapidly during the first 30 minutes of incubation of bacteria and soil particles in aqueous media, and increased gradually with incubation time up to $300 \mathrm{~min}$. In some cases, adsorption rates fluctuated after $30 \mathrm{~min}$ of incubation, probably due to bacterial cell sorption to and de-sorption from soil particles. Using Freundlich isotherms, it was noted that adsorption coefficient related to adsorption capacity varied from 19 to 4026 E. coli. $\mathrm{mg}^{-1}$ of soil, and from 506 to 847 Salmonella sp. $\mathrm{mg}^{-1}$ of soil. For both bacterial species, the adsorption coefficient of layer $\mathrm{H}_{Y}$ (located in close proximity of the water table) was greater than that of $\mathrm{H}_{\mathrm{X}}$ (located above layer $\mathrm{H}_{\mathrm{Y}}$ ) and seemed to positively correlate with the $\mathrm{pH}$ values and N/P ratios, and to negatively correlate with the values of $\mathrm{C} / \mathrm{N}$ and $\mathrm{C} / \mathrm{P}$ ratios. The linearity coefficient related to adsorption intensity varied from 0.5841 to 1.0023 for $E$. coli, and from 0.7068 to 1.5236 for Salmonella sp. The physico-chemical characteristics of soil particles seemed to influence the sorption kinetics of bacteria on soil.
\end{abstract}

Key words: soil sorption kinetics, Escherichia coli, Salmonella sp.

\section{Introduction}

Bacterial movement in soil is important in the pollution follow-up of the surface and underground waters. In general, it requires the presence of water. Bacterial movements and transportation in soil and in underground water can occur by adsorption-desorption mechanisms, by filtration or by advection-scattering [1, 2]. This movement in underground water is influenced by the hydrodynamics and hydro-mechanical coefficients of bacterial scattering, water diffusion coefficient, the coefficient of active mobility of bacteria, the gradient of bacterial concentration, the velocity of underground water movement and retardation factor, magnitude of each parameter varying according to geological conditions and physiological and anatomical status of bacterial cells [3-5]. Their persistence and survival in these underground media also are significantly influenced by the concentration of indigenous micro-organisms, their growth and decay rates, the concentration of available nutrients and the consumption kinetics, among others $[2,6]$.

Adsorption is the main process leading to a retarded bacterial transport in soil and underground water [2]. It is sometimes a reversible process that evolves in time, due to bacterial activity and variations of bacterial wall 
properties [7-9]. Hydrophobicity is the main bacterial wall property which is involved in the cell adhesion on particles [10]. Stability of this adhesion depends on the number of sites and groups of functional sites properties on the bacterial surface, the sites number expected to vary with the chemical characteristics of the environment [11]. Bacterial exopolysaccharide matrix has been indicated as containing many chemically active sites involved in sorption process [12]. Bacterial sorption in aqueous medium is also impacted by the $\mathrm{pH}$, ionic strength, chemicals, the nature of sorbent particle and its mobility coefficients $[8,9,13]$.

In many regions of the world, groundwater is still the main source of drinking water supply. Most studies have indicated the pollution of this underground water resource by faecal bacteria such as Escherichia coli and Streptococcus feacalis, and by opportunistic bacteria such as Aeromonas hydrophila and Pseudomonas aeruginosa, distribution of bacteria being impacted by some chemical factors $[14,15]$. The presence of such organisms is indicative of the existence of pathogenic bacteria such as Salmonella typhi and Vibrio cholerae which can cause health hazards. In most African countries, wastewaters containing faecal and non faecal bacteria are often discharged to the environment without any pre-treatment, and therefore, can potentially pollute soil and groundwater. Knowledge of the adsorption capacity and kinetics of bacterial retention in soil could contribute to the scientific understanding of the microbiological quality of groundwater in specific soil types. The main purpose of this research was to assess the sorption kinetics of Escherichia coli and Salmonella $s p$. on two soil layers collected above a groundwater table in Yaounde, Cameroon (Central Africa).

\section{Materials and Methods}

\section{Soil Collection}

The Yaounde region in Cameroon (Central Africa) is located at latitude $3^{\circ} 52^{\prime} \mathrm{N}$, longitude $11^{\circ} 32^{\prime} \mathrm{E}$, with average altitude of $760 \mathrm{~m}$. Its soil is fero-lateritic [16]. A circular hole of $180 \mathrm{~cm}$ of diameter on a site out of the urban area was dug until the appearance of the groundwater table. This hole measured $914 \mathrm{~cm}$ depth and crossed 8 different soil layers. These layers were named from top (surface) to bottom (groundwater table) as $\mathrm{H}_{1}, \mathrm{H}_{2}, \mathrm{H}_{3}, \ldots, \mathrm{H}_{8}$. In this paper, $\mathrm{H}_{7}$ is referred to as $\mathrm{H}_{\mathrm{X}}$ and $\mathrm{H}_{8}$ as $\mathrm{H}_{\mathrm{Y}}$. Two to three $\mathrm{kg}$ samples from each of these two soil layers $\left(\mathrm{H}_{\mathrm{X}}\right.$ and of $\left.\mathrm{H}_{\mathrm{Y}}\right)$ were collected and dried at laboratory room temperature $\left(23 \pm 1^{\circ} \mathrm{C}\right)$ for 12 months.

\section{Physical and Chemical Properties of Soil Layers}

Soil layer $\mathrm{H}_{\mathrm{X}}$ is made up of yellowish brown material. There is appearance of whitish cracked patches and translucent quartz grains. It has polyedric structure. Soil horizon $\mathrm{H}_{\mathrm{Y}}$ is made up of whitish to yellowish clay with silt patches. Purple red to dark brown patches, quartz grains and quartzo-feldspathic beddings and little compact material are observed. Soil colours were determined using Munsel code [17]. Analysed chemicals included $\mathrm{pH}$, iron $(\mathrm{Fe})$, organic carbon $(\mathrm{C})$, total nitrogen $(\mathrm{N})$ and total phosphorus (P). $\mathrm{pH}$ values were recorded according to Soil Analysis Handbook of Reference Methods [18]. Chemical analyses were carried out after mineralization of soil samples using triacid technique attack [19]. Fe, $\mathrm{N}$ and $\mathrm{P}$ were then analysed using spectrophotometer, and $\mathrm{C}$ was analysed using heat potassium dichromate oxidation method [20]. Each measure has been done in duplicate.

\section{Bacteria Isolation and Identification}

The faecal bacterium E. coli was isolated from waste water, using membrane filtration technique, on the Endo culture medium (Bio-Rad laboratories, France), and identified by usual biochemical criteria [21, 22]. After identification, a suspension has been done from Colony Forming Units (CFUs) cultivated by plate count method on standard agar medium (Diagnostics-Pasteur, France), in petri dish. From the suspension, culture of this strain has also been done, but on standard agar medium slant in test tube, and stored at $6-8^{\circ} \mathrm{C}$ for later use.

Salmonella $s p$ was isolated from the Mingoa stream, a tributary of the Mfoundi hydrographic system in Yaounde. This isolation was performed using membrane filtration technique, on Wilson-Blair culture agar medium (Bio-Rad laboratories, France). It firstly necessitated a pre-enrichment in peptone water aiming in the recover of stressed bacteria, then an enrichment in the Müller-Kauffman culture medium (Bio-Rad laboratories, France), this medium being selective for Salmonella. Biochemical identification then was done using enzymatic tests [21]. From CFUs on standard agar medium in petri dishes, pure culture of this strain has also been done on standard agar medium slant in the test tube, as for $E$. coli. It has then been stored at $6-8^{\circ} \mathrm{C}$, for later use.

\section{Assessment of Soil Sorption Potential}

It was not been possible to perform experiments with the same bacteria cell inoculums as great variations in concentrations of growing cells were observed when inoculums were stored at $6-8{ }^{\circ} \mathrm{C}$. Each test was thus carried out with cells obtained from colony forming units on standard agar culture media. Separate experiments were carried out with E. coli, and Salmonella sp.

A bacterial colony from standard agar medium was introduced in a $250 \mathrm{ml}$ flask containing $50 \mathrm{ml}$ of sterile physiological solution ( $\mathrm{NaCl} 0.85 \%$ ), and the content was mixed by shaking. The bacterial concentration in this solution was determined using membrane filtration technique. The concentration at the initial instant $\left.\left(\mathrm{t}_{0},\right)\right)$ in the absence of soil represented $\mathrm{C}_{0}$. It was noted that bacterial colonies were of different cells quantities. A weight of crushed soil of a definite layer was then added in that solution. Soil samples were not sterilized as high temperature or pressure would destroy soil minerals and alter its physico-chemical properties. During preliminary analyses, neither E. coli nor Salmonella $s p$ was found in the 2 studied soil layers. The samples were mixed with bacterial solutions in flasks and then incubated on a GLF 3018 Model shaker at $110 \mathrm{rpm}$ for 300 minutes at 
laboratory temperature $\left(23 \pm 1{ }^{\circ} \mathrm{C}\right)$. For each of the two soil layers, experiments were carried out with $500 \mathrm{mg}$, $200 \mathrm{mg}, 100 \mathrm{mg}$ and $50 \mathrm{mg}$ samples. (It has been noted during preliminary analyses that the number of bacterial cells per CFU vary significantly from one colony to another. For this reason, it has been concluded not necessary to replicate tests as initial concentration $\mathrm{C}_{0}$ of planktonic cells will greatly differ from one test to another for the same soil weight sample). The test period of 300 minutes was chosen in according to results of preliminary analyses which showed that it was sufficient for the saturation of sites of soil particles surfaces.

For bacterial analyses, $1 \mathrm{ml}$ of solution contained in the flask was sampled. Dilutions and analyses to determine planktonic (non adsorbed on soil particles) bacterial concentrations were then performed using membrane filtration technique [22]. Endo culture agar medium was used to isolate planktonic E. coli, and Wilson-Blair culture agar medium was used to isolate Salmonella $s p$. Numbers of cells were determined and expressed as colony forming units (CFUs). From initial instant $t_{0}$, the bacterial analysis to determine planktonic cells was carried out at 15,30 and after each 30 minutes, during the incubation period. The number of bacterial cells adsorbed on soil particles at each analysis was determined knowing cell concentration at initial instant $\mathrm{t}_{0}$. This method was adapted from Wang et al [12] and Miller et al [23].

\section{Data Analysis}

Freundlich and Langmuir isotherms have been extensively used for evaluation of adsorption processes parameters [12, 23, 24]. Sorption data of E. coli and Salmonella $s p$ on soil particles were analysed with Freundlich model to evaluate the kinetics parameters in the sorption process. Langmuir isotherm has not been used due to the variability of the number of adhesion sites groups on adsorbent particles [11], the mobility and the interactions generally noted amongst absorbed cells [9, $25]$ and considering the assumption of the heterogeneous nature of adsorbent particles on soil layers [12, 24].

Freundlich isotherm (non-linear) equation, according to Miller et al [23] and Wang et al [12], is described by equation:

$$
\mathrm{C}_{\mathrm{s}}=\mathrm{K}_{\mathrm{f} \cdot} \mathrm{C}^{1 / n}
$$

where $\mathrm{C}_{\mathrm{s}}$ is the amount of adsorbate adsorbed by adsorbent, $\mathrm{C}$ is the equilibrium concentration of non adsorbed, $\mathrm{K}_{\mathrm{f}}$ is the Freundlich adsorption coefficient and it is related to adsorption capacity, $1 / n$ is the linearity exponent and $n$ is related to adsorption intensity. Here, $\mathrm{C}_{\mathrm{s}}$ is expressed as number of cells. $\mathrm{mg}^{-1}$ of soil and $\mathrm{C}$ as number of cells.ml ${ }^{-1}$. When $\log \mathrm{C}_{\mathrm{s}}$ was plotted against $\log \mathrm{C}$, a straight line with slope $1 / n$ and intercepting $\log \mathrm{K}_{\mathrm{f}}$ was obtained.

\section{Results and Discussion}

Decrease in planktonic cells concentration expresses cells sorption on soil particles. Adsorption of microbial cells on geological particles seems to swiftly take place during the 15 or 30 minutes that follow bacterial switch on soil particles in aqueous phase (Figures 1-2). This was noted from concentration of planktonic cells which decreases quickly during the first 30 minutes that follow incubation. After this period, concentration of nonattached bacteria decreases slowly, while undergoing in some cases fluctuations that are sometimes of important magnitude. Variation in the number of sorbed cells indicated the reversibility of bacterial process on soil particles. (During preliminary analyses, blank sorption experiments were performed in the absence of soils, and no variation occurred in bacterial concentration. It was concluded that all observed changes in bacterial concentration in the presence of soils could be attributed to sorption by soil particles).

Equilibrium instant was considered as the moment at which the number of adsorbed E. coli or Salmonella $s p$, is the greatest (the concentration of planktonic cells is the lowest) during each experiment. Considering the absorbed bacterial number and the concentration of planktonic bacteria at equilibrium for each of performed tests, Freundlich isotherms have been established for each soil horizon (Figure 3). Isotherms parameters $\mathrm{K}_{\mathrm{f}}$ and $1 / n$ have been obtained by linearly regressing data of the systems. Adsorption coefficient $\left(\mathrm{K}_{\mathrm{f}}\right)$ of $E$. coli was 19. $\mathrm{mg}^{-1}$ and $4026 . \mathrm{mg}^{-1}$ of soil, for $\mathrm{H}_{\mathrm{X}}$ and $\mathrm{H}_{\mathrm{Y}}$ respectively; that of Salmonella $s p$ was $506 . \mathrm{mg}^{-1}$ and 846. $\mathrm{mg}^{-1}$ for horizon $\mathrm{H}_{\mathrm{X}}$ and $\mathrm{H}_{\mathrm{Y}}$ respectively (Table 1). Linearity exponent $(1 / n)$ varied from 0.5841 to 1.5236 . The highest value was for Salmonella $s p$ on $\mathrm{H}_{\mathrm{X}}$ and the lowest was for $E$. coli on horizon $\mathrm{H}_{\mathrm{Y}}$ (Table 1). Lower linearity coefficient implies bacterial adsorption intensity relatively great and greater linearity coefficient implies adsorption intensity relatively low. Higher value of adsorption coefficients implies greater adsorption capacity and lower adsorption coefficient implies lower soil particles adsorption capacity. Variability in this soil adsorption potential would be due to the variability of the number of adhesion sites groups on adsorbent particles [11]. Some authors working on bacterial sorption on clean quartz sand yielded adsorption isotherms that linearity coefficients varied from 0.55 to 6.11 , and adsorbed bacterial number at equilibrium of about $6.93 \times 10^{5}$ cells.mg ${ }^{-1}[26]$.

Table 1: Adsorption coefficient $\left(\mathrm{K}_{\mathrm{f}}\right)$ and linearity coefficient $(1 / n)$ values

\begin{tabular}{lcccc}
\hline & \multicolumn{2}{c}{ E. coli } & \multicolumn{3}{c}{ Salmonella sp } \\
\cline { 2 - 5 } Horizon & $\left.\begin{array}{c}\mathrm{K}_{\mathrm{f}} \\
\text { (E. Coli.mg }\end{array} \mathrm{m}^{-1}\right)$ & $1 / n$ & $\begin{array}{c}\mathrm{K}_{\mathrm{f}} \\
(\text { Salmonella } \\
\text { sp.mg }\end{array}$ & $1 / n$ \\
\hline $\mathrm{H}_{\mathrm{X}}$ & 19 & 1.0023 & 506 & 1.5236 \\
$\mathrm{H}_{\mathrm{Y}}$ & 4026 & 0.5841 & 847 & 0.7068 \\
\hline
\end{tabular}



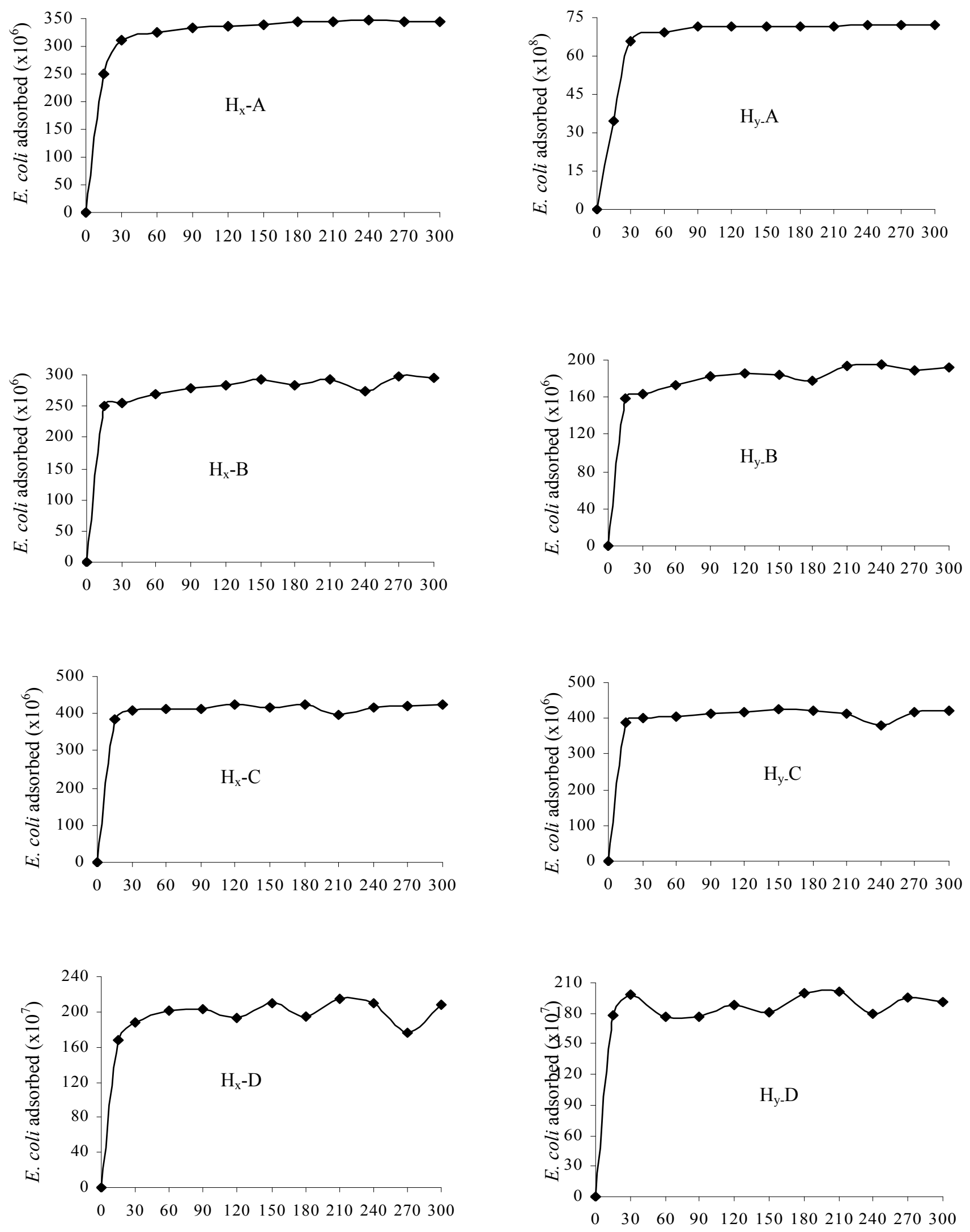

Incubation time (minutes)

Incubation time (minutes)

Figure 1: Temporal variations of adsorbed E. coli.mg-1 of soil particles, tests carried out with $500 \mathrm{mg}$ (A), $200 \mathrm{mg}$ (B), $100 \mathrm{mg}$ (C) and $50 \mathrm{mg}$ (D) of soil horizon $\mathrm{H}_{\mathrm{X}}$ and $\mathrm{H}_{\mathrm{Y}}$. 

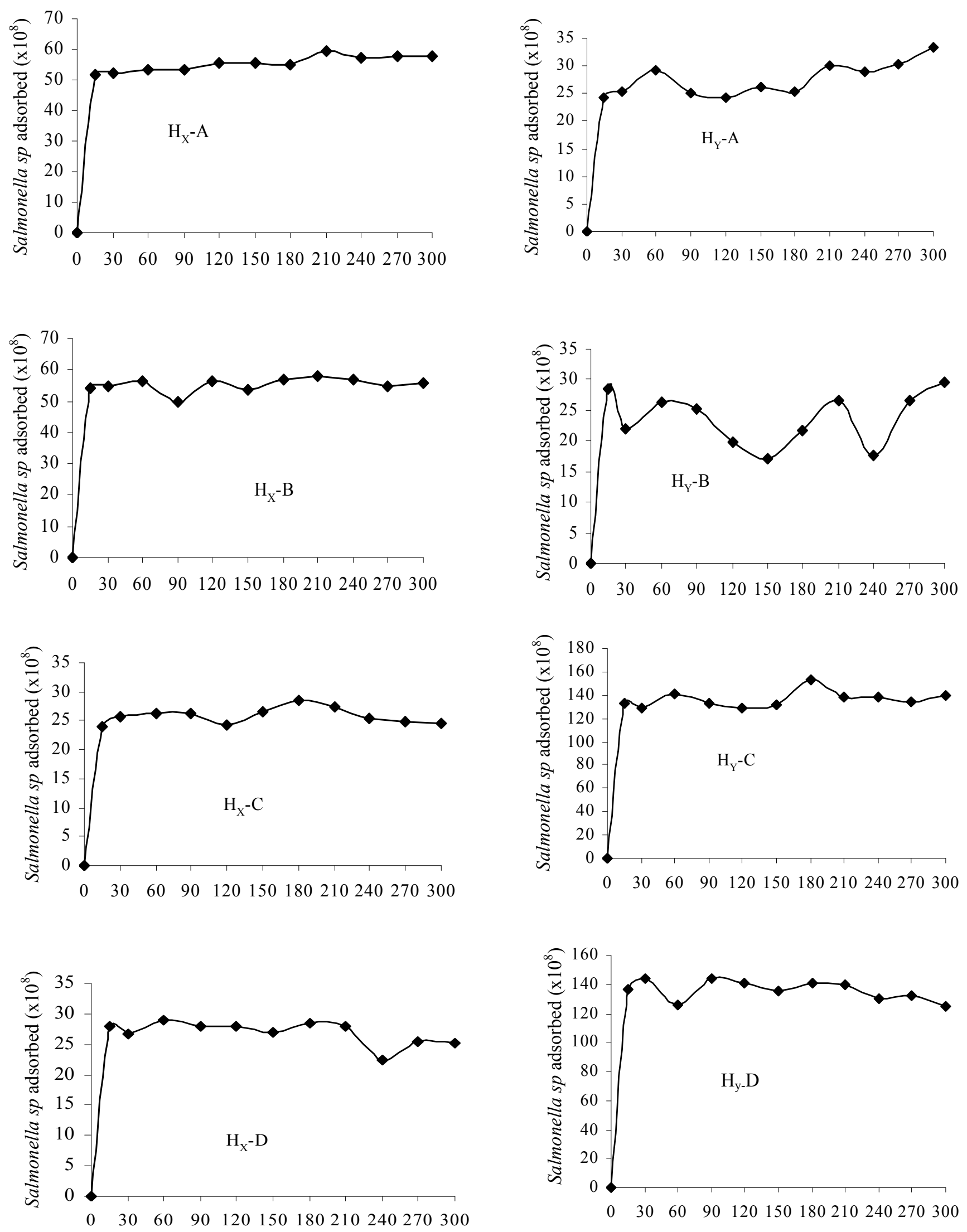

Incubation time (minutes)

Incubation time (minutes)

Figure 2: Temporal variations of adsorbed Salmonella sp.mg-1 of soil particles, tests carried out with $500 \mathrm{mg}$ (A), $200 \mathrm{mg}$ (B), $100 \mathrm{mg}$ (C) and $50 \mathrm{mg}$ (D) of soil horizon $\mathrm{H}_{\mathrm{X}}$ and $\mathrm{H}_{\mathrm{Y}}$. 

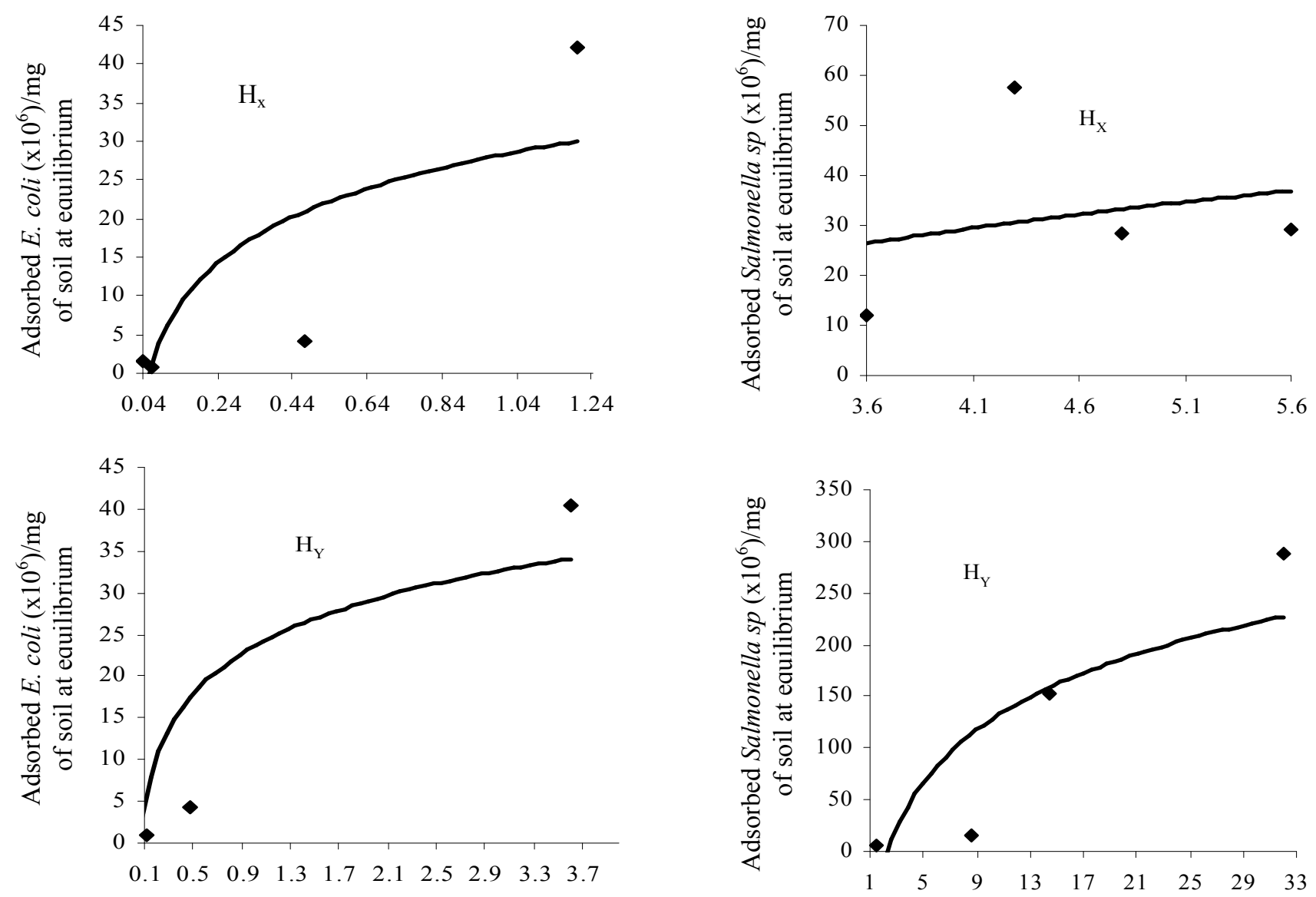

Planktonic E. coli $\left(\times 10^{6} / \mathrm{ml}\right)$ at equilibrium

Planktonic Salmonella $s p\left(\times 10^{6} / \mathrm{ml}\right)$ at equilibrium

Figure 3: Adsorption isotherms of E. coli and Salmonella sp on soil horizons $\mathrm{H}_{\mathrm{X}}$ and $\mathrm{H}_{\mathrm{Y}}$

Table 2: Mean (standard deviation) of values of $\mathrm{pH}$ and the concentrations ( $\mathrm{mg}^{-\mathrm{g}^{-1}}$ of soil) in carbon (C), iron (Fe), total nitrogen $(\mathrm{N})$ and total phosphorus $(\mathrm{P})$ of soil horizon $\mathrm{H}_{\mathrm{X}}$ and $\mathrm{H}_{\mathrm{Y}}$

\begin{tabular}{lcccccccc}
\hline Horizon & $p H$ & $C$ & $F e$ & $N$ & $P$ & $C / N$ & $C / P$ & $N / P$ \\
\hline & 4.435 & 4.140 & 0.749 & 0.100 & 17.425 & 41.400 & 0.237 & 0.005 \\
$\mathrm{H}_{\mathrm{X}}$ & $(0.007)$ & $(0.056)$ & $(0.004)$ & $(0.000)$ & $(0.077)$ & $(0.565)$ & $(0.002)$ & $(0.000)$ \\
& & & & & & & & \\
& & & & & & & & \\
$\mathrm{H}_{\mathrm{Y}}$ & $(0.559$ & 4.315 & 0.697 & 0.235 & 26.145 & 18.454 & 0.164 & 0.007 \\
& & $(0.091)$ & $(0.024)$ & $(0.021)$ & $(0.091)$ & $(2.056)$ & $(0.002)$ & $(0.000)$ \\
\hline
\end{tabular}

The two soil layers were of different chemical characteristics (Table 2). The concentration of $\mathrm{C}, \mathrm{N}$, and $\mathrm{P}$, and the $\mathrm{pH}$ values increase from $\mathrm{H}_{\mathrm{X}}$ to $\mathrm{H}_{\mathrm{Y}}$, while $\mathrm{Fe}$ concentration decreases from $\mathrm{H}_{X}$ to $\mathrm{H}_{\mathrm{Y}}$. The $\mathrm{pH}$ values of soil of this region have also been noted by Bachelier[16] and Yongue-Fouateu [27] as acid, varying from 4 to 5 with depending on the layer. According to Jewett et al [28], bacterial sorption to surfaces is not significantly affected at $\mathrm{pH} 5-9$, although a perceptible decrease in this factor can sometimes increase the retention of E. coli, Pseudomonas aeruginosa and of Salmonella infentis, due to surface physico-chemical interactions between cells and soil particles [29]. Haas and Dichristina [30] working on Shewanella putrefaciens noted that sorption sites density on its wall varied according to the environmental $\mathrm{pH}$ and was 0.57 site per $\mathrm{nm}^{2}$ in acid and 0.40 site per $\mathrm{nm}^{2}$ in base conditions.

Cell sorption swiftly took place during the first 30 minutes following the introduction of bacteria in the aqueous medium containing soil particles (Figures 1-2). This swift sorption was also noted during the first 45 minutes of experiments by Scholl and Harvey [31]. It has been noted that 2 types of strengths exist in such medium: attractive forces lead the cells polymers 
adhesion on particles surfaces, and repulsive strengths that compress cellular envelopes to a minimal energy resulting from Derjaguin-Landau-Verwey-Overbeek$\mathrm{AB}$ (DLVO-AB) interactions [5]. The partition of this process in swift initial phase and late slow phase would be related to the passivity of initial phase and to the energy-dependence of late phase. According to Simoni et al [32], adsorption process is less energy-dependent indeed passive at the beginning, and turns to more energy-dependent phenomenon as incubation duration becomes longer, probably due to the restriction of bacterial sorption sites number.

It has been noted that bacterial sorption to surfaces is due to adhesin which is an hydrophobic protein of molecular weight greater than $10 \mathrm{kDa}$, located at the cellular surface or in the cytoplasm [33]. Its activity is inhibited in the presence of antiadhesin which is a hydrophobic non proteinic and heat-sensitive compound [34]. Many interactions have been indicated to be among adhered bacteria and they can significantly influence their structure and their physiology [35]. These interactions sometimes proteins-mediated, have also been observed between bacteria and yeasts, yeasts adhering weakly to particles due to their large size [35]. Interactions also exist between soil particles that are invariant and bacterial cell surfaces which depend on the bacterial physiological condition [4]. They often lead to the sorption reversibility [36] and would be one of the origins of the irregular fluctuations of the number of sorbed E. coli or Salmonella sp sometimes observed during experiments (Figures 1-2). Changing from planktonic to the adhered state, and conversely exert a regulation on some genes, although the nature of the signal sent to gene when cell is attached is not clear [37, 38]. It is noted from Figure 3 that except Salmonella $s p$ on horizon $\mathrm{H}_{\mathrm{X}}$, adsorbed cell number increase swiftly at lower equilibrium planktonic cell concentrations. Adsorption isotherm of Salmonella $s p$ on horizon $\mathrm{H}_{\mathrm{X}}$ would express a relatively less complexity of systems [24], and would depend according to Sotelo et al [39] on the lower difference in interactions energies among equilibriums.

Layers $\mathrm{H}_{\mathrm{X}}$ and $\mathrm{H}_{\mathrm{Y}}$ are of different adsorption coefficients and linearity coefficients. Adsorption coefficients for each of bacterial species increase from $\mathrm{H}_{\mathrm{X}}$ to $\mathrm{H}_{\mathrm{Y}}$ (Table 1). Some authors have observed a considerable increase in polymers adhesion production by $E$. coli with increasing in environmental $\mathrm{C} / \mathrm{N}$ ratios [40]. In this study, $\mathrm{C} / \mathrm{N}$ and $\mathrm{C} / \mathrm{P}$ ratios rather decrease from $\mathrm{H}_{\mathrm{X}}$ to $\mathrm{H}_{\mathrm{Y}}$, and $\mathrm{N} / \mathrm{P}$ ratios increase from $\mathrm{H}_{\mathrm{X}}$ to $\mathrm{H}_{\mathrm{Y}}$ (Table 2). Microbial adhesion on particles has also been indicated as related to the microbial surface thermodynamic theory which is impacted by environmental conditions, physiological status of microorganism and its surface structure [4, 41]. It is noted that linearity coefficient for both bacterial species decreases from $\mathrm{H}_{\mathrm{X}}$ to $\mathrm{H}_{\mathrm{Y}}$ (Table 1). It is also noted that concentration in $\mathrm{Fe}$ decreases from $\mathrm{H}_{\mathrm{X}}$ to $\mathrm{H}_{\mathrm{Y}}$ (Table 2). No relation has yet been established between iron concentration in soil horizon and linearity coefficient either for E. coli or Salmonella sp. Some authors have indicated that iron hydroxide reinforces ionic strength's action of bacilli sorption [26], but probably without significant impact on cocci bacterial sorption [42].

Surface thermodynamic properties of gram-negative bacteria as E. coli and Salmonella $s p$ are influenced by moisture contents of surrounding environment as outer surface of the membrane is high in lipid contents and low in peptidoglycan contents [43]. Although chemicalssuch as rhamnolipids that affect sorption reversibility by increasing negative electrical charges in the medium [44], and calcium that reinforces chemical links favouring specific and non specific interactions in the presence of protein and polysaccharide molecules of adhesion, and strengthening calcic bridges among cells $[45,46]$-affect microbial adhesion to surfaces, no definite chemical influence has been clearly demonstrated in the present study. However, E. coli and Salmonella $s p$ retention on soil layers could be highly influenced by the physico-chemical properties of soil particles.

\section{Conclusions}

This study demonstrated that two soil layers collected above a groundwater table in Yaounde, Cameroon, present significant differences in their physical properties and chemical characteristics. They also showed substantial differences in their sorption kinetics and retention potentials for both Escherichia coli and Salmonella sp. Sorption kinetics seemed to result from interactions between bacterial cells and soil particles, and to depend on both soil type and bacterial species. However, the correlation between bacterial sorption and soil chemistry remains to be elucidated.

Acknowledgments: This work was supported by grant from Fonds International de Coopération Universitaire FICU (Agence Universitaire de la Francophonie), and by AIRE développement (grant ref.: 01-2-CMR-31-1).

\section{References}

1. Matthess, G.; Pekdeger, A.; Schroeter, J.: Persistence and transport of bacteria and viruses in groundwater - A conceptual evaluation. J. Contam. Hydrol. 1988, 2, 171-188.

2. Teutsch, G.; Herbold-Paschke, K.; Tougianidou, D.; Hahn, T.; Botzenhart, K.: Transport of microorganisms in the underground-processes, experiments and simulation models. Wat. Sci. Technol. 1991, 24, 309-314.

3. Harvey, R. W.; Garabedian, S. P.: Use of colloid filtration theory in modeling movement of bacteria through a contaminated sandy aquifer. Environ. Sci. Technol. 1991, 25, 178-185.

4. Grasso, D.; Smets, B. F.; Strevett, K. A.; Machinist, B. D.; Van Oss, C. J.; Giese, R. F.; Wu, W.: Impact of physiological state on surface thermodynamics and adhesion of Pseudomonas aeruginosa. Environ. Sci. Technol. 1996, 30, 3604-3608.

5. Jucker, B. A.; Zehnder, A. J. B.; Harms, H.: Quantification of Polymer Interactions in Bacterial Adhesion. Environ. Sci. Technol. 1998, 32, 2909-2915. 
6. Banton, O.; Bangoy, L. M.: Hydrogéologie, Multiscience environnementale des eaux souterraines, Puq/Aupelf, Sainte-Foy, 1997, 460 p.

7. Rijnaarts, H. H. M.; Norde, W.; Bouwer, E. J.; Lyklema, J.; Zehnder, A. J. B.: Reversibility and mechanism of bacterial adhesion. Colloids and Surfaces B: Biointerfaces 1995, 4, 5-22.

8. Fowle, D. A., Fein, J. B.: Experimental measurements of the reversibility of metal-bacteria adsorption reactions. Chemical Geology, 2000, 168, 27-36.

9. Yee, N.; Fein, J. B.; Daughney, C. J.: Experimental study of the $\mathrm{pH}$, ionic strength, and reversibility behavior of bacteria-mineral adsorption. Geochimica and Cosmochimica Acta 2000, 64, 609-617.

10. Van Der Mei, H.C.; Bos, R.; Busscher, H. J.: A reference guide to microbial cell surface hydrophobicity based on contact angles. Colloids and Surfaces B: Biointerfaces, 1998, 11, 213-221.

11. Fein, J.B.; Daughney, C.J.; Yee, N.; Davis, T. A.: A chemical equilibrium model for metal adsorption onto bacterial surfaces. Geochimica and Cosmochimica Acta 1997, 61, 3319-3328.

12. Wang, W.; Wang, W.; Zhang, X.; Wang, D.: Adsorption of p-chlorophenol by biofilm components. Wat. Res. 2002, 36, 551-560.

13. Camesano, T. A.; Logan, B. E.: Influence of fluid velocity and cell concentration on the transport of motile and nonmotile bacteria in porous media. Environ. Sci. Technol. 1998, 32, 1699-1708.

14. Nola, M.; Njine, T.; Sikati, F. V.; Djuikom E: Distribution de Pseudomonas aeruginosa et Aeromonas hydrophila dans les eaux de la nappe phréatique superficielle en zone équatoriale au Cameroun et relations avec quelques paramètres chimiques du milieu. Rev. Sci. Eau, 2001, 14, 35-53.

15. Nola, M.; Njine, T.; Djuikom, E.; Sikati Foko, V.: Faecal coliforms and faecal streptococci community in the underground water in an equatorial area in Cameroon (Central Africa): the importance of some environmental chemical factors. Wat. Res., 2002, 36, 3289-3297.

16. Bachelier, G.: Etude pédologique des sols de Yaoundé. Contribution à l'étude de la pédogenèse des sols ferralitiques. Agron. Tropic., 1959, 14, 279305.

17. Macbeth Division of Kollmorgen Corporation: Determination of soil color-Munsel soil color charts. Macbeth Division of Kollmorgen Corporation, Baltimore, Maryland, 1975, $141 \mathrm{p}$.

18. Beck, R., Kalra, Y., Vaughan, B., Wolf, A. M.: Soil analysis - Handbook of Reference Methods, CRC Press LLC, New York, 2000, 247 p.

19. Njopwouo, D., Orliac, M.: Note sur le comportement de certains minéraux à l'attaque triacide. Cah. ORSTOM Sér. Pédol., 1979, 17, 329-337.

20. Rodier, J.: L'analyse de l'eau - Eaux naturelles, eaux résiduaires, eau de mer, Dunod, Paris, 1996, $1384 \mathrm{p}$.

21. Marchal, N.; Bourdon, J. L.; Richard, Cl.: Milieux de culture pour l'isolement et l'identification biochimique des bactéries, Doin, Paris, 1991, 509 p.
22. Ford, L. A.: Detection of Aeromonas salmonicida from water using a filtration method. Aquaculture 1994, 122, 1-7.

23. Miller, M. J.; Critchley, M. M.; Hutson, J.; Fallowfield, H. J.: The adsorption of cyanobacterial hepatotoxins from water onto soil during batch experiments. Wat. Res. 2001, 35, 1461-1468.

24. Schijven, J. F.; Hassanizadeh, S. M.: Removal of viruses by soil passage: overview of modeling, processes and parameters. Crit. Rev. Environ. Sci. Tech. 2000, 30, 49-127.

25. Kolter, R.; Losick, R.: One for all and all for one. Science 1998, 280, 226-227.

26. Mills, A. L.; Herman, J. S.; Hornberger, G. M.; Dejesus, T. H.: Effect of solution ionic-strength and iron coatings on mineral grains on the sorption of bacterial-cells to quartz sand. Appl. Environ. Microbiol. 1994, 60, 3300-3306.

27. Yongue-Fouateu, R.: Contribution à l'étude pétrographique de l'altération et des faciès de cuirassement ferrugineux des gneiss migmatitiques de la région de Yaoundé, Thèse Doctorat, Université de Yaoundé, 1986, 214 pp.

28. Jewett, D. G.; Hilbert, T. A.; Logan, B. E.; Arnold, R. G.; Bales, R. C.: Bacterial transport in laboratory column and filters - Influence of ionic strength and $\mathrm{pH}$ on collision efficiency. Wat. Res. 1995, 29, 1673-1680.

29. Klanova, K.: Effect of chemical fertilizers on the transport of Escherichia coli, Pseudomonas aeruginosa and Salmonella infentis through sand columns. Folia Microbiologica, 1994, 39, 283-286.

30. Haas, J.; Dichristina, T.: Thermodynamics of reversible proton exchange and metal sorption onto Shewanella putrefaciens. J. Conference Abstracts 2000, 5, 464.

31. Scholl, M. A.; Harvey, R. W.: Laboratory investigations on the role of sediments surface and groundwater chemistry in transport of bacteria through a contaminated sandy aquifer. Environ. Sci. Technol., 1992, 26, 1410-1417.

32. Simoni, S. F.; Harms, H.; Bosma, T. N. P.; Zehnder, A. J. B.: Population heterogeneity affects transport of bacteria through sand columns at low rates. Environ. Sci. Technol., 1998, 32, 2100-2105.

33. Nikolaev, Y. A.: Role of long-range interactions in the regulation of adhesion of Pseudomonas fluorescens cell. Mikrobiologiya, 2000, 69, 356-361.

34. Nikolaev, Y. A.; Prosser, J. I.: Some properties of Pseudomonas fluorescens adhesion and antiadhesin. Mikrobiologiya 2000, 69, 237-242.

35. Millsap, K. W.; Van Der Mei, H. C.; Bos, R.; Busscher, H. J.: Adhesive interaction between medically important yeasts and bacteria. FEMS Microb. Rev., 1998, 21, 321-336.

36. James, G. A.; Beaudette, L.; Costerton, J. W.: Interspecies bacterial interactions in biofilms. $J$. Industrial Microbiol.. 1995, 15, 257-262.

37. Brozel, V. S.; Strydom, G. M.; Cloete, T. E.: A method for the study of de-novo protein-synthesis in Pseudomonas aeruginosa after attachment. Biofouling, 1995, 8, 195-201. 
38. O’toole, G.; Kaplan, H. B.; Kolter, R.: Biofilms formation as microbial development. Ann. Rev. Microbiol., 2000, 54, 49-79.

39. Sotelo, J. L.; Ovejero, V.; Delgado, J. A.; Martinez, I.: Comparison of adsorption equilibrium and kinetics of four chlorinated organics from water onto GAC. Wat Res., 2002, 36, 599-608.

40. Huang, C. -T.; Peretti, S. W.; Bryers, J. D.: Effect of medium carbon-to-nitrogen ratio on biofilm formation and plasmid stability. Biotechnol. Bioeng., 1994, 44, 329-336.

41. Chen, G.; Strevett, K. A.: Impact of surface thermodynamics on bacterial transport. Environ. Microbiol., 2001, 3, 237-245.

42. Knapp, E. P.; Herman, J. S.; Hornberger, G. M.; Mills, A.: The effect distribution of ironoxyhydroxide grain coatings on the transport on bacterial cell in porous media. Environ. Geol., 1998, 33, 243-248.

43. Nikaido, H.; Yaara, M.: The molecular basis of bacterial outer membrane permeability. Microbiol. Rev., 1985, 49, 1-32.

44. Bai, G. Y.; Brusseau, M. L.; Miller, R. M.: Influence of rhamnolipide biosurfactant on the transport of bacteria through a sandy soil. Appl. Eviron. Microbiol. 1997, 63, 1866-1873.

45. Geesey, G. G.; Wigglesworth-Cooksey, B.; Cooksey, K. E.: Influence of calcium and other cations on surface adhesion of bacteria and diatoms: a review. Biofouling, 2000, 15, 195-205.

46. Jeljaszewicz, J.; Mlynarczyk, A.; Mlynarczyk, G.: Exoproteins in Staphylococcus aureus virulence. Bulletin of the Pollish Academy of Sciences Biological Sciences, 2000, 48, 77-98. 